\title{
Skokochrony jako alternatywne rozwiązanie względem asekuracyjnych siatek bezpieczeństwa do ochrony zbiorowej podczas prac na wysokości
}

\author{
Szymon Molski ${ }^{1} \mathbb{D}$, Jerzy Kwaśniewski ${ }^{1} \mathbb{D}$, Mariusz Gołkowski ${ }^{2}$, \\ Józef Grzybowski ${ }^{3}$ (D), Justyna Czyż ${ }^{4}$ \\ 1 AGH Akademia Górniczo-Hutnicza, Wydział Inżynierii Maszyn i Robotyki, Kraków \\ 2 Centrum Badawczo-Rozwojowe CBR Rock Master Sp. z o. o. Sp. k. \\ 3 Politechnika Rzeszowska im. Ignacego Łukasiewicza, Wydział Budowy Maszyn i Lotnictwa \\ 4 Polish Intelligent Logic Controllers PILC Józef Grzybowski
}

\begin{abstract}
Streszczenie: Siatki bezpieczeństwa, asekuracyjne stanowią jeden z najlepszych sposobów ochrony zbiorowej podczas prac na wysokości. Są często stosowane na budowach, w czasie remontów, jako ekonomiczne, wygodne w transporcie zabezpieczenie przed upadkiem z wysokości ludzi lub przedmiotów. Mogą zastępować ciężkie rusztowania (siatkowe platformy robocze) czy też balustrady (siatki pionowe, barierkowe). Zajmują mniej miejsca i są mniej wymagające, jeżeli chodzi o transport. W artykule przedstawiono wyniki dwóch prób dynamicznego zrzutu manekina typu Hybrid III na skokochrony będące alternatywnym rozwiązaniem wobec dotychczasowego systemu zabezpieczenia przed upadkiem z wysokości z wykorzystaniem siatek bezpieczeństwa. Analiza otrzymanych wyników potwierdza, że skokochrony mogą być z powodzeniem stosowane w ochronie przed upadkiem z wysokości, spełniając wymagania opisane w stosownych normach bezpieczeństwa.
\end{abstract}

Słowa kluczowe: bezpieczeństwo, skokochrony, pomiar przyspieszeń

\section{AIRBAGS - AN ALTERNATIVE TO SAFETY NETS AS COLLECTIVE FALL PROTECTION FOR WORK AT HEIGHT}

\begin{abstract}
Safety nets and safety nets are one of the best methods of collective protection during work at height. They are often used on construction sites, during renovations as an economical, convenient in transport protection against falls from a height of people or objects. They can replace heavy scaffolding (mesh working platforms) or railings (vertical and barrier nets). They take up less space and are less demanding when it comes to transport. The article presents the results of two attempts to dynamically drop the Hybrid III dummy onto jumping cushions, which are an alternative solution to the existing fall protection system with the use of safety nets. The analysis of the obtained results confirms that the jump cushions can be successfully used in protection against falls from a height, meeting requirements described in the relevant safety standards.
\end{abstract}

Keywords: safety, airbags, acceleration measurements

https://doi.org/10.7494/978-83-66727-47-2_8 


\section{Wstęp}

Siatki bezpieczeństwa, asekuracyjne stanowią jeden z najlepszych sposobów ochrony zbiorowej podczas prac na wysokości. Są często stosowane na budowach, podczas remontów jako ekonomiczne, wygodne w transporcie zabezpieczenie przed upadkiem z wysokości ludzi lub przedmiotów. Mogą zastępować ciężkie rusztowania (siatkowe platformy robocze) czy też balustrady (siatki pionowe, barierkowe). Zajmują mniej miejsca i są mniej wymagające, jeżeli chodzi o transport.

Dodatkowo wyposażone są w linę krawędziową, za pomocą której siatka mocowana jest do konstrukcji. Produkowane są z polipropylenu o podwyższonej wytrzymałości (siatki polipropylenowe) z oczkami $10 \mathrm{~cm} \times 10 \mathrm{~cm}$ lub 4,5 cm $\times 4,5 \mathrm{~cm}$ i są wykonane z linek grubości 4-5 mm. Przykładowo siatka bezpieczeństwa typu T do zabezpieczania krawędzi budynku ma następujące cechy:

- siatka polipropylenowa o oczku $100 \mathrm{~mm} \times 100 \mathrm{~mm}$ wyposażona jest w linkę graniczną do ochrony osób przed upadkiem z wysokości i jest zintegrowana z siatką osłonową stanowiącą zabezpieczenie przed upadkiem przedmiotów,

- siatka jest mocowana w poziomie na wsporniku 6,0 $\mathrm{m} \times 3,2 \mathrm{~m}$, który jest kotwiony do stropu budynku,

- system zabezpiecza na wypadek upadku z 6 m,

- montaż, przenoszenie i demontaż systemu wymagają użycia dźwigu.

System jest zaprojektowany i wyprodukowany na podstawie obowiązujących przepisów oraz norm bezpieczeństwa PN-EN 1263-1:2015-2 (2015) i PN-EN 1263-2:2015-2 (2015), dotyczących siatek bezpieczeństwa zabezpieczających przed upadkiem z wysokości.

Uzasadnieniem podjęcia tematyki wykorzystania skokochronów do ochrony zbiorowej podczas prac na wysokości jest aspekt techniczny. Często zdarzają się sytuacje, w których nie można zastosować siatek bezpieczeństwa. Przeprowadzone pomiary mają na celu wykazanie słuszności założonej tezy, że zdwojony układ skokochronów może zastąpić powszechnie stosowane asekuracyjne siatki bezpieczeństwa. W artykule zamieszczono wyniki badań dotyczące prób zrzutu manekina z wysokości stosowanej w badaniu siatek asekuracyjnych.

\section{Skokochrony jako rozwiązanie alternatywne wobec siatek bezpieczeństwa}

Pomysłodawcą skokochronu był John Tom Scurlock (1926-2008). Urodził się w 1926 roku w Center w Teksasie, gdzie jeszcze przed wojną ukończył Center High School. Następnie rozpoczął naukę na Uniwersytecie A\&M w Teksasie, którą przerwał 
z powodu powołania do armii amerykańskiej i udziału w działaniach wojennych na frontach Europy. Po kilku latach pobytu w Stuttgarcie wrócił do USA, by dokończyć naukę w A\&M w Teksasie, uzyskując z tytuł licencjata nauk ścisłych i magistra w dziedzinie elektrotechniki. Następnie został profesorem na Uniwersytecie Tulane'a oraz równolegle pracował dla NASA jako specjalista od tworzyw sztucznych. Ten bardzo wykształcony $\mathrm{w}$ wielu dziedzinach naukowiec wpadł pod koniec lat 50. na pomysł nadmuchiwanego poszycia namiotów do kortów tenisowych. Założył firmę, by komercjalizować swoje liczne pomysły. W 1958 roku założył Space Walk Inc. W kolejnych latach powstały takie wynalazki jak powietrzna „space pillow”, używana przez hollywoodzkich kaskaderów oraz - co dla nas najbardziej interesujące - skokochron ratowniczy. Podobno głównym impulsem do zajęcia się tematem poduszek ratowniczych był pożar w Rault Center w 1972 roku, w którym zginęło pięć osób. To tragiczne wydarzenie doprowadziło do wynalezienia w 1973 i opatentowania w roku 1974 skokochronu.

Jak podaje Komenda Główna PSP, pierwszy skokochron, który otrzymał „dokument dopuszczający” CNBOP w dniu 7.06.1993 roku, był żółto-biały, napełniany z dwóch wentylatorów, a wyprodukowany był przez Klaus Esser KG. Obecnie tych urządzeń w polskiej straży jest ponad 400 (w tym głównie w jednostkach PSP, ale także w nielicznych jednostkach OSP).

Pierwszy zapis o skokochronach pojawił się w rozporządzeniu Ministra Spraw Wewnętrznych z dnia 3 listopada 1992 roku w sprawie ochrony przeciwpożarowej budynków, innych obiektów budowlanych i terenów, gdzie w $§ 21$ zapisano: „Do sprzętu i urządzeń ratowniczych zalicza się w szczególności: 1) rękawy ratownicze, linkowe aparaty ratownicze, skokochrony oraz inny sprzęt do ratownictwa bezpośredniego z wysokości”.

Dokumentem normatywnym traktującym o bezpieczeństwie jest norma DIN 14151-3-2016-08 Poduszki ratunkowe - Część 3: Poduszka do skoków typu 16 - Wymagania, testowanie (DIN 14151-3, 2016).

Skokochrony mogą być alternatywnym rozwiązaniem względem siatek bezpieczeństwa, jednak ich zastosowanie wymaga przeprowadzenia stosownych prób i badań opisanych poniżej.

\section{Kalibracja systemu diagnostycznego hybrydowego manekina testowego Hybrid III 95th Large Male ATD}

W badaniach wykorzystano manekin Humanetics Hybrid III 95th Large Male ATD (rys. 1), który - na podstawie badań antropometrycznych - jest reprezentatywny dla największego segmentu populacji dorosłych ludzi (Bartsch i in. 2012). 95-centylowy 
manekin jest wykorzystywany na całym świecie do oceny samochodowych i wojskowych urządzeń bezpieczeństwa. Hybrid III 95M został pierwotnie opracowany w 1988 roku przez First Technology Safety Systems (następnie Humanetics) i Society of Automotive Engineers (SAE) (Tanaka i in. 2009).

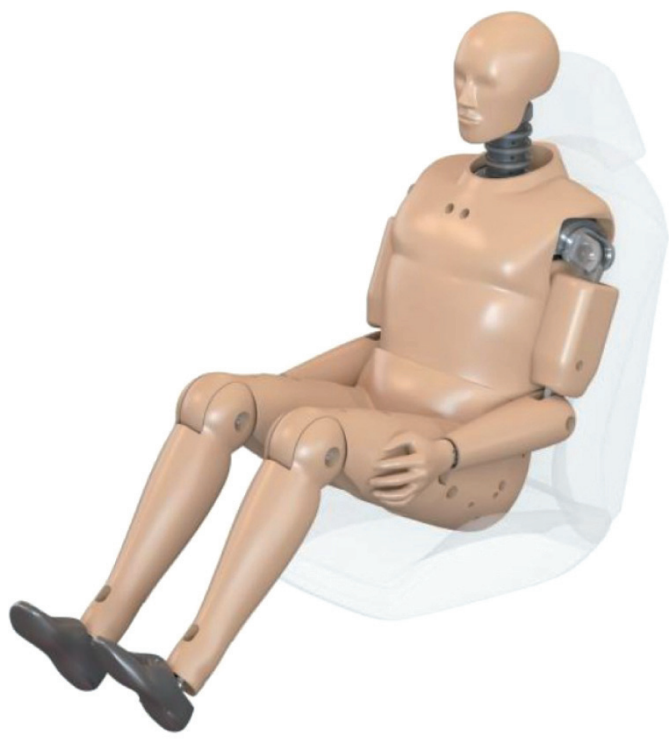

Rys. 1. Manekin testowy Hybrid III 95th o masie $95 \mathrm{~kg}$ Źródło: PILC Józef Grzybowski (2021)

\subsection{Wyposażenie pomiarowe}

W skład systemu PRP-W2, którego producentem jest firma PILC, wchodzi szereg modułów:

- PCDL-01 (rejestrator danych zapisujaccy dane na kartę pomiarową),

- PCAH-01 (moduł AHRS).

Układ AHRS jest zespołem przetworników zawierających trójosiowe akcelerometry, trójosiowe przetworniki prędkości kątowej oraz trójosiowy magnetometr. Procesor układu AHRS wylicza kąty orientacji przestrzennej na podstawie wszystkich sygnałów wyjściowych z wymienionych przetworników:

- PCAI-01 (interfejs analogowy, użyto 2 szt.),

- moduł czujnika przyspieszeń (użyto 5 szt., które znajdowały się w rękach, nogach i głowie).

Blok akwizycji danych - system BAD, którego producentem jest firma PILC sp. z o.o. jest niezależnym modułem mierzącym oraz rejestrującym takie dane, jak: przyspiesze- 
nia, prędkości kątowe, kąty orientacji przestrzennej, wysokość barometryczna oraz czas pomiaru. Dane zapisywane są na kartę pamięci SD.

\subsection{Metoda pomiarowa}

Zapis przyspieszeń działających na kończyny i środek ciężkości manekina Hybrid III realizowany jest przyspieszeniomierzami MEMS z wyjściem napięciowym. Pomiar napięć i zapis na karcie pamięci SD wykonywany był rejestratorem systemu PRP-W2. Odczyt i analiza zarejestrowanych danych realizował program nadzorujaccy system PRP-W2.

\subsection{Montaż rejestratora na manekinie}

Elementy wchodzące w skład systemu PRP-W2 zostały zamontowane na rękach i nogach oraz wewnątrz brzucha i głowy manekina. Montaż elementów systemu PRP-W2 wykonano przed rozpoczęciem badań. System zamontowano w taki sposób, aby oś $\mathrm{Z}$ przyspieszeniomierzy pokrywała się z linią kręgosłupa, a oś Y z linią wyciągniętej w bok prawej ręki (rys. 2).

System BAD to jednoelementowy moduł, który zamontowano na środku klatki piersiowej (rys. 3) podczas zakładania uprzęży na manekin przed zrzutem.

System PRP W2 ustawiony jest do rejestracji przyspieszeń chwilowych (zaprogramowano próbkowanie $10 \mathrm{~ms}$ ).

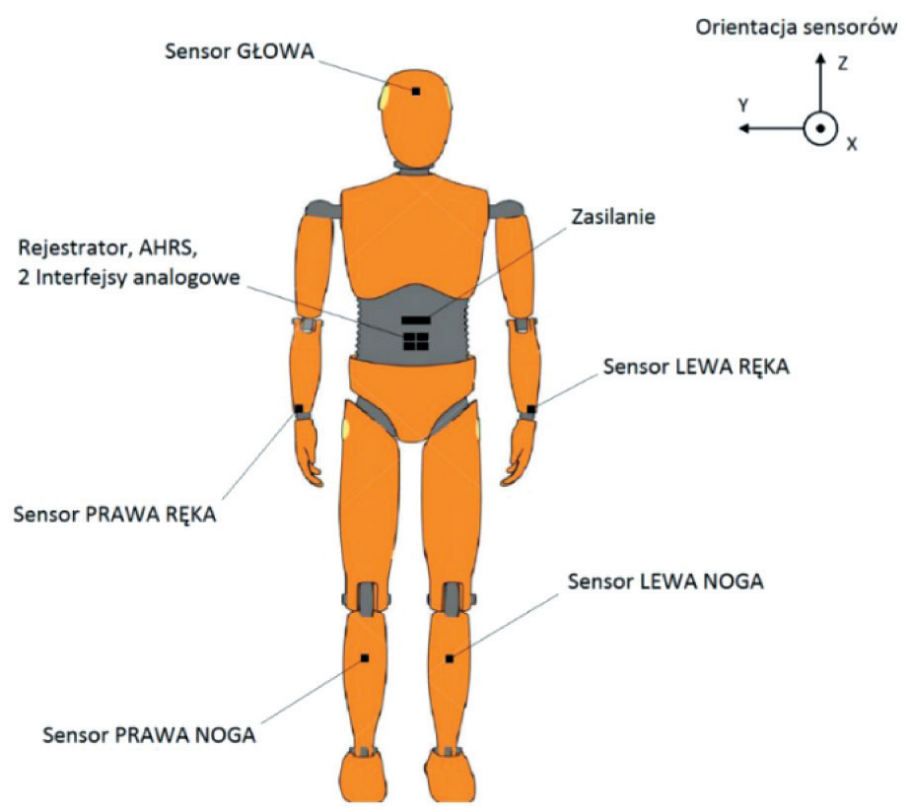

Rys. 2. Rozmieszenie elementów systemu pomiarowego PRP-W2 


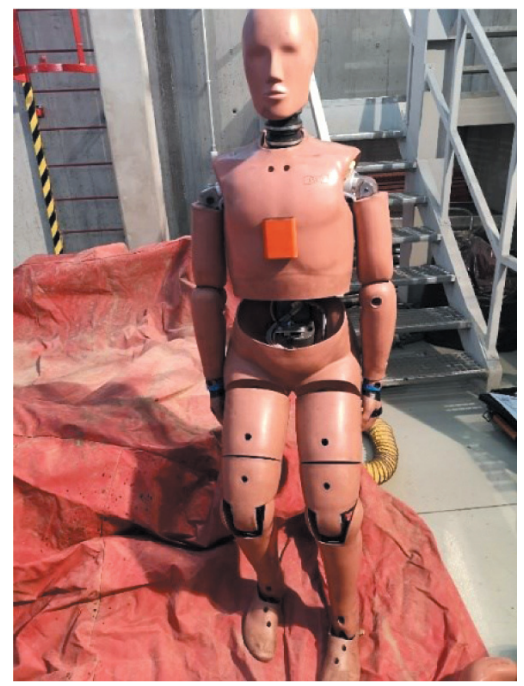

Rys. 3. Montaż rejestratora BAD na klatce piersiowej

\subsection{Kalibracja systemu diagnostycznego}

Wykorzystane trójosiowe przyspieszeniomierze typu ADXL326 o zakresie od $-16 \mathrm{~g}$ do $+16 \mathrm{~g}$ wytwarzają sygnał analogowy unipolarny w zakresie $0-3 \mathrm{~V}$ ze średnią czułością $57 \mathrm{mV} / \mathrm{g}$.

Po zamontowaniu przyspieszeniomierzy oraz pozostałych elementów systemu pomiarowego na manekinie przeprowadzono kalibrację systemu. Podłączony został interfejs umożliwiający kalibrację i bieżący podgląd na laptopie aktualnych wartości wysyłanych przez przyspieszeniomierze. Do kalibracji wykorzystano kierunek i zwrot wektora grawitacji (przyciągania ziemskiego). Wymuszone wartości charakterystyczne $(-1 \mathrm{~g}, 0 \mathrm{~g},+1 \mathrm{~g})$ dla każdego przyspieszeniomierza i poszczególnych jego osi X, Y, Z zostały zapisane w pamięci nieulotnej i były reprezentowane słowem binarnym 32 bit.

Przyłączone do sensorów dwa interfejsy pomiarowe (PCAI-01) z 16 wejściami analogowymi przesyłają na magistralę CAN wartości binarne do rejestratora z okresem próbkowania $10 \mathrm{~ms}$ dla pełnego kadru danych. Na podstawie wymuszeń $+1 \mathrm{~g}, 0 \mathrm{~g},-1 \mathrm{~g}$ zarejestrowanym wartościom binarnym automatycznie przeliczana i przyporządkowana jest wartość przyspieszenia $[\mathrm{g}]$ dla poszczególnych kanałów pomiarowych. Rysunek 4a pokazuje wymuszenie wartości $1 \mathrm{~g}$ dla lewej ręki manekina i wizualizację sygnału z magistrali CAN na komputerze nadzorującym.

Po zakończeniu kalibracji, w celach weryfikacyjnych, wykonano próbną rejestrację danych zebranych poprzez uderzenie w trzech osiach poszczególnych obszarów „ciała” manekina, w których zamontowano sensory pomiarowe. Rejestrator danych zgromadził parametry pochodzące ze wszystkich kanałów interfejsów analogowych, co zostało 
zweryfikowane przy użyciu dedykowanego oprogramowania nadzorującego system PRP-W2 (wizualna weryfikacja danych na wykresie graficznym) (rys. 4b).

a)

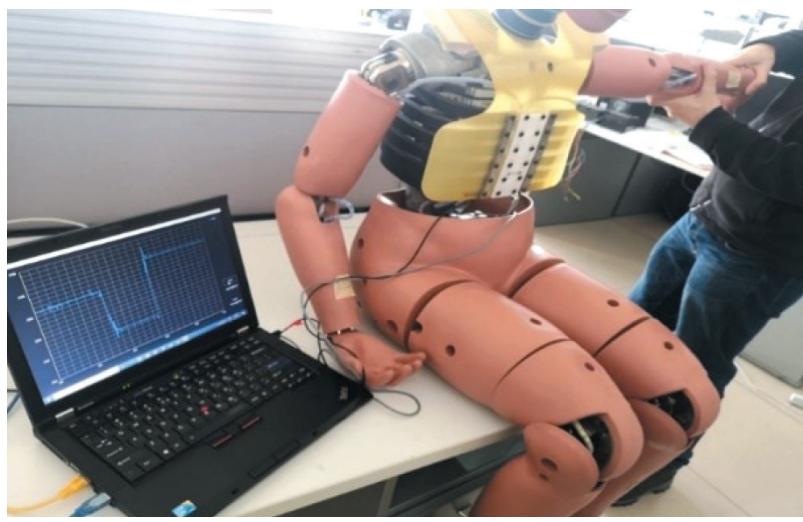

b)

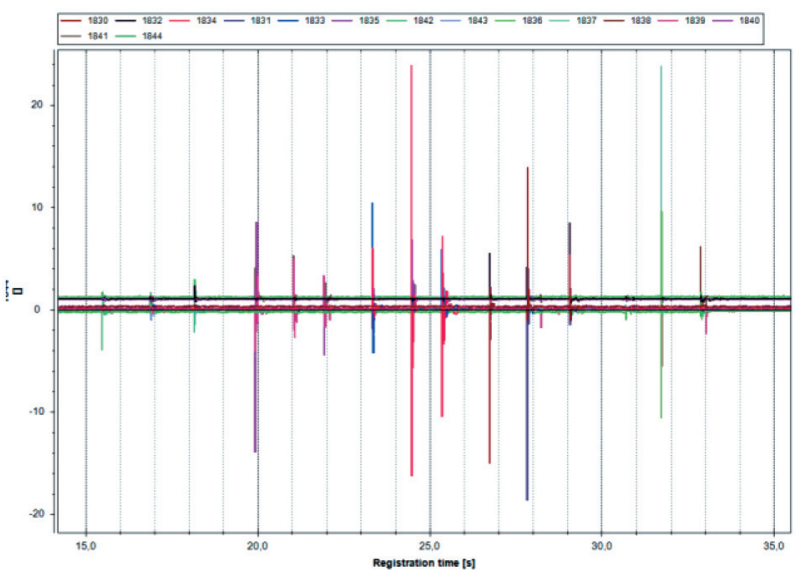

Rys. 4. Wymuszenie ruchu lewej ręki manekina (a) i wizualizacja rejestrowanych zmian przyspieszenia (b)

Bezpośrednio przed zrzutami manekina na poduszki dodatkowo sprawdzono sprawność sensorów i rejestratora, co polegało na wprowadzaniu w ruch poszczególnych kończyn manekina i jego głowy przez generowanie krótkotrwałych zmian przyspieszeń. Dzięki temu zabiegowi na wykresach graficznych można było zaobserwować zmianę wartości przyspieszenia rejestrowaną przez poszczególne przyspieszeniomierze. Analogiczna procedura wykonana została dla niezależnego rejestratora BAD.

\subsection{Badania dynamiczne - zrzuty manekina}

Przedmiotem badań wykonanych w CBR Rock Master sp. z o.o. sp. k. był układ czterech poduszek skokochronu połączonych ze sobą, zajmujących powierzchnię 
$6 \mathrm{~m} \times 6 \mathrm{~m}$, ułożonych w jednej i w dwóch warstwach. Manekin zrzucano w teoretycznie najniebezpieczniejsze miejsce stanowiące centralny punkt łączonych poduszek. Manekina zrzucono w pozycji „lecacej na plecy”:

- na podwójną warstwę poduszek (o łącznej wysokości 3 m), z wysokości 15 m (czyli dystans pomiędzy pozycją początkową manekina a powierzchnią poduszek wynosił $12 \mathrm{~m}$ ) (rys. 5);

- na pojedynczą warstwę poduszek (o łącznej wysokości 1,5 m nad podłożem), z wysokości 7,5 m (czyli dystans pomiędzy pozycją początkową manekina a powierzchnią poduszek wynosił $6 \mathrm{~m}$ ) (rys. 6).

Analizie poddano zapisy z czujników umieszczonych w głowie oraz na klatce piersiowej. Na układy warstwy poduszek nałożona była siatka, która w wyniku upadku manekina przemieszczała się „do środka - między poduszki”. Istnieje prawdopodobieństwo, że manekin wpadając między poduszki, w przypadku zastosowania jednej ich warstwy, mógłby uderzyć o podłoże (rys. 6).

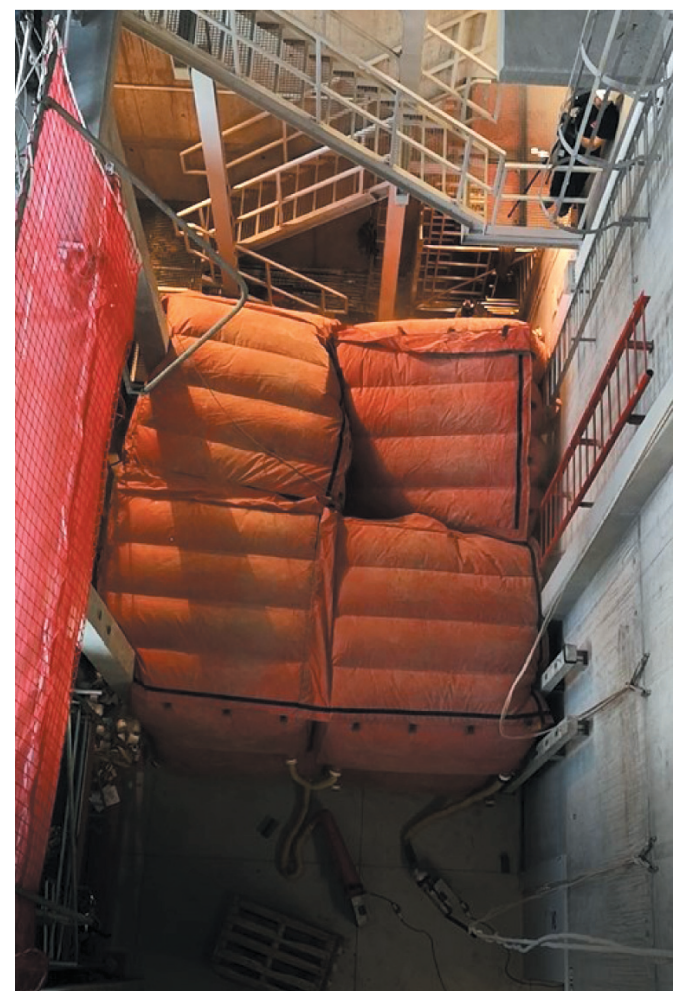

Rys. 5. Miejsce upadku manekina podczas zrzutu na podwójną warstwę poduszek zrzut nr 1 


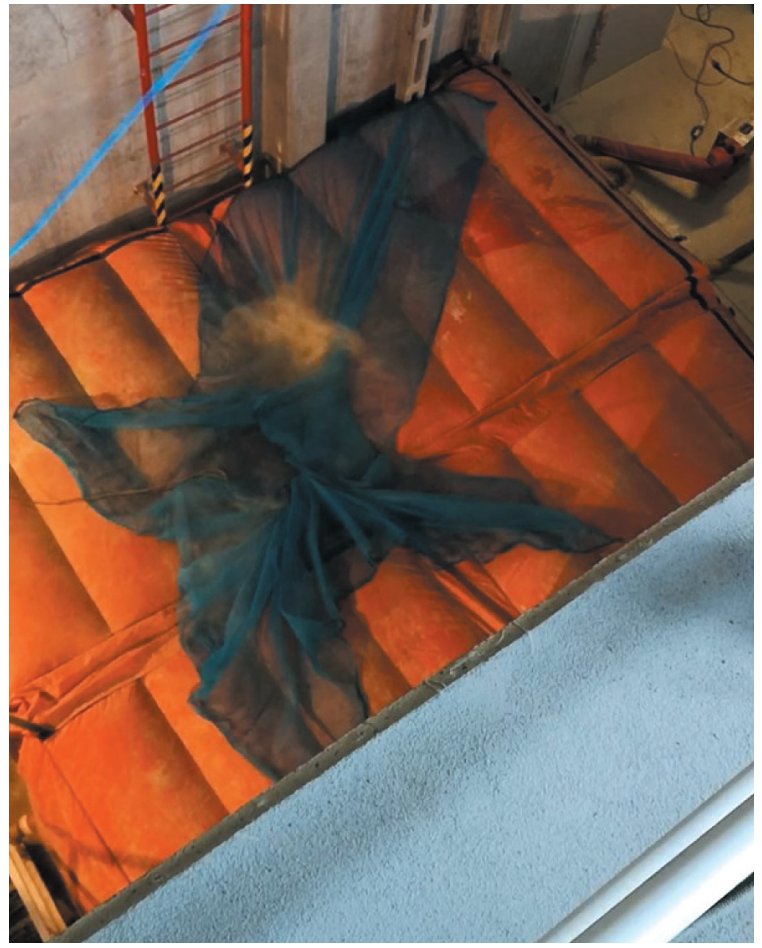

Rys. 6. Miejsce upadku manekina podczas zrzutu na pojedynczą warstwę poduszek zrzut nr 2

\subsubsection{Badania podwójnego układu poduszek (zrzut nr 1)}

\section{Głowa}

Analizując zaprezentowane na rysunku 7 wartości przyspieszeń chwilowych, jakie zarejestrował czujnik umieszczony wewnątrz głowy manekina (zgodnie z rysunkiem 2), można zauważyć, że najpierw zadziałały przyspieszenia o wartościach dodatnich na osiach $\mathrm{X}=+22,94 \mathrm{~g}(59,05 \mathrm{~s}) ; \mathrm{Y}=+10 \mathrm{~g}$ (59,07 s), co odzwierciedla kolejno ruch głowy „do przodu”; „w prawo”. Wartości przyspieszeń chwilowych na osiach X, Y wynosiły powyżej $+5 \mathrm{~g} \mathrm{w}$ czasie około $0,05 \mathrm{~s}$. Wartości przyspieszeń chwilowych, jakie zadziałały na osi $\mathrm{Z}$, zmieniły się z dodatnich na ujemne oraz ponownie na dodatnie w znacznie bardziej dynamiczny sposób niż na pozostałych dwóch osiach. Zarejestrowane wartości $\mathrm{Z}$ w danych momentach pomiaru wynosiły: $\mathrm{Z}=+7,03 \mathrm{~g}$ (59,01 s); $\mathrm{Z}=-1,29 \mathrm{~g}$ (59,06 s); $\mathrm{Z}=+14,29 \mathrm{~g}(59,07 \mathrm{~s}) ; \mathrm{Z}=-2,87 \mathrm{~g}(59,08 \mathrm{~s}) ; \mathrm{Z}=+2,05 \mathrm{~g}(59,1 \mathrm{~s})$. Najniższe wartości przyspieszeń chwilowych, jakie zarejestrowano dla osi $\mathrm{X}$ oraz $\mathrm{Y}$, wyniosły: $\mathrm{X}=-10,75 \mathrm{~g}$ (59,16 s); $\mathrm{Y}=-9,46 \mathrm{~g}$ (59,16 s). Przyspieszenia na osiach wykraczające poza przedział $\{-2 \mathrm{~g}$ do $+3 \mathrm{~g}\}$ wystąpiły łącznie w czasie około $0,35 \mathrm{~s}$. 
Zarejestrowane wartości przyspieszeń, które wystąpiły w czasie dłuższym niż kilka milisekund, mogą (ale nie muszą) oznaczać ryzyko uszkodzenia kręgosłupa szyjnego.

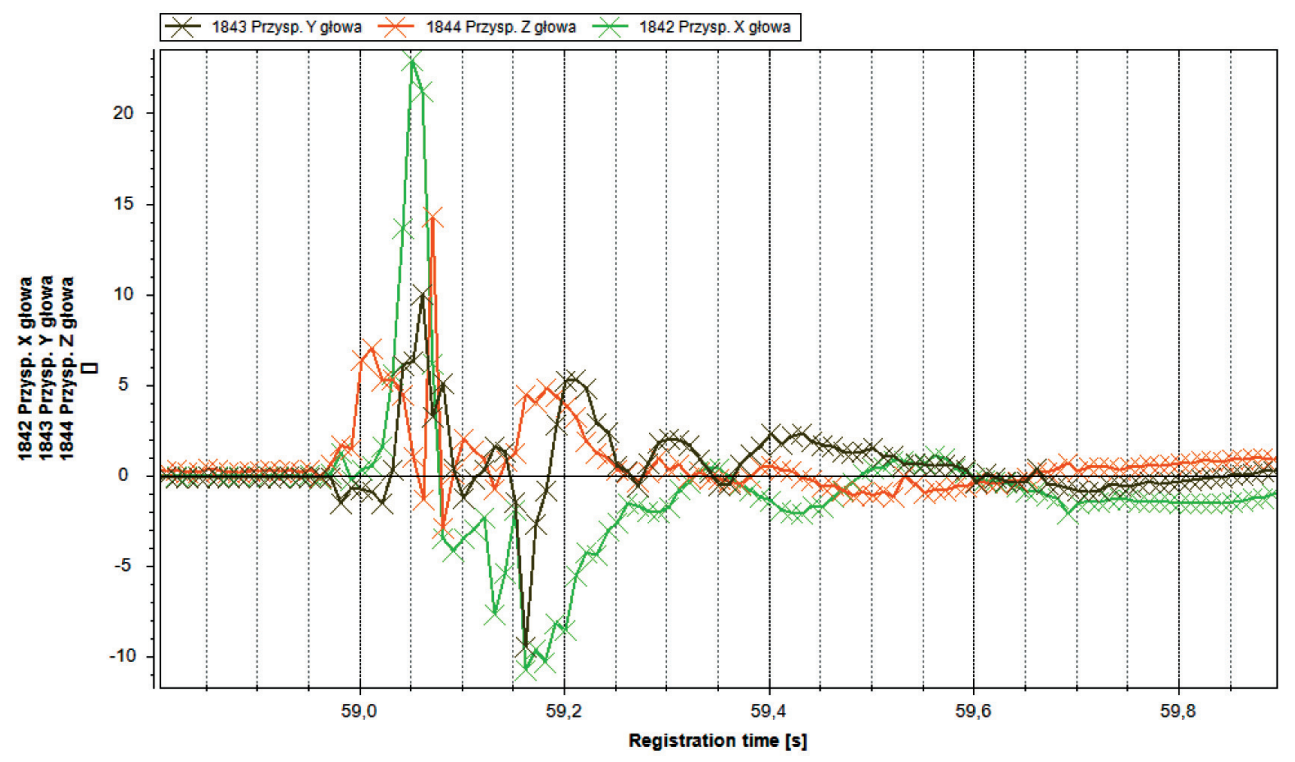

Rys. 7. Przyspieszenia [g] zarejestrowane przez sensor umieszczony wewnątrz głowy manekina

\section{Środek ciężkości}

Przyjęto, że środek ciężkości znajduje się w miejscu, gdzie umieszczono układ odniesienia AHRS (rys. 2). Największa wartość przyspieszeń chwilowych wyniosła: wzdłużne $\mathrm{a}_{\mathrm{X}}=+14,9 \mathrm{~g}(59,04 \mathrm{~s})$; boczne $\mathrm{a}_{\mathrm{Y}}=+13,72 \mathrm{~g}(59,07 \mathrm{~s})$; normalne $\mathrm{a}_{\mathrm{Z}}=+5,82 \mathrm{~g}(59,01 \mathrm{~s})$. Najmniejsza wartość przyspieszeń chwilowych (bezpośrednio po uderzeniu o materac bądź beton pomiędzy poduszkami wyniosła: wzdłużne $\mathrm{a}_{X}=+1,08 \mathrm{~g}(59,07 \mathrm{~s})$; boczne $\mathrm{a}_{Y}=-2,99 \mathrm{~g}(59,01 \mathrm{~s})$; normalne $\mathrm{a}_{Z}=-2,66 \mathrm{~g}(59,04 \mathrm{~s})$. Na wykresie (rys. 8) widać, że przyspieszenie boczne oraz normalne miało znacznie większą dynamikę zmian wartości niż przyspieszenie wzdłużne. Przyspieszenia na osiach wykraczające poza przedział $\{-2 \mathrm{~g}$ do $+3 \mathrm{~g}\}$ wystąpiły łącznie w czasie około 0,2 s.

Urządzenie BAD jest specjalnym rejestratorem do badań parametrów lotu i zrzutu skoczków spadochronowych. Umieszczony został na klatce piersiowej manekina, co pokazano na rysunku 3.

Maksymalne wartości zarejestrowanych przyspieszeń bezpośrednio po upadku na podwójne poduszki zabezpieczające (rys. 9) podano poniżej:

- przyspieszenie wzdłużne $\mathrm{a}_{X}=3,54 \mathrm{~g}$ (w 65,66 s),

- przyspieszenie boczne $\mathrm{a}_{\mathrm{Y}}=-4,74 \mathrm{~g}(\mathrm{w} 65,80 \mathrm{~s})$,

- przyspieszenie normalne $\mathrm{a}_{\mathrm{Z}}=1,74 \mathrm{~g}$ (w 65,62 s). 


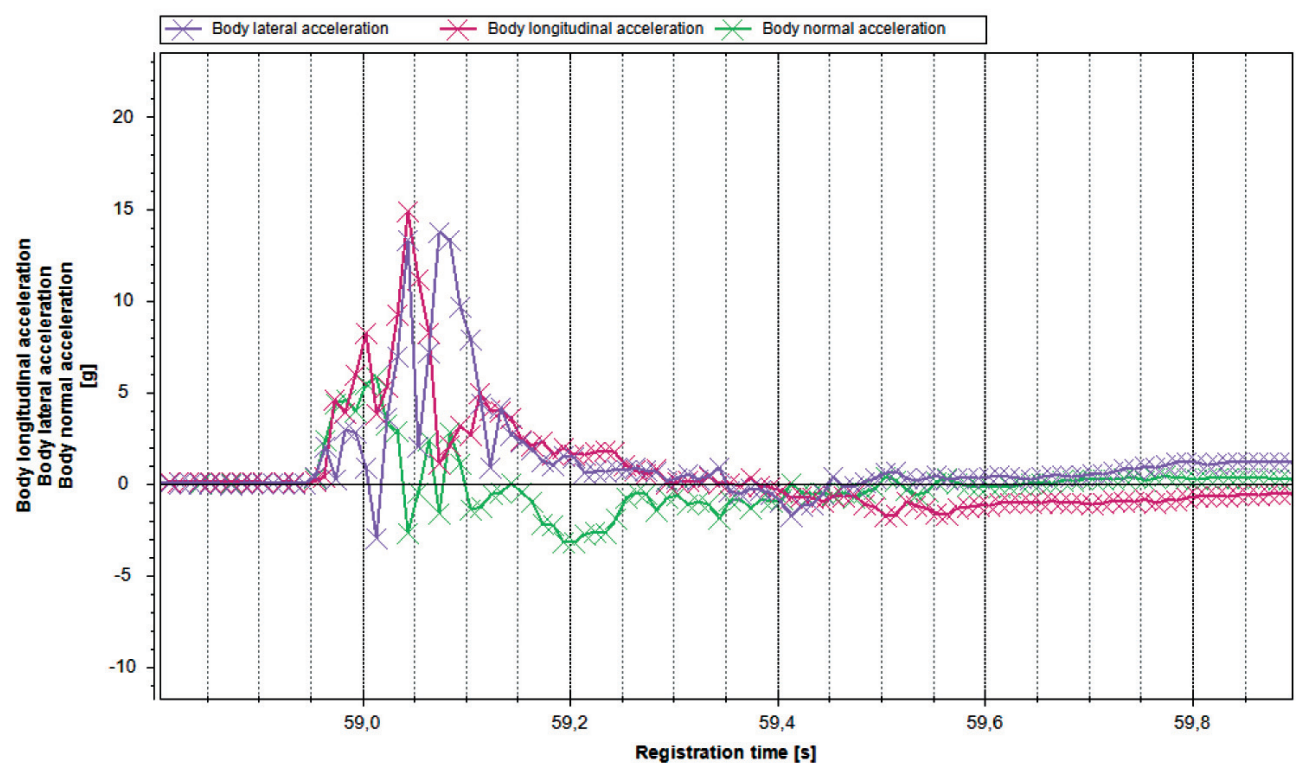

Rys. 8. Dane z AHRS - środek ciężkości (przyspieszenia: $a_{X}, a_{Y}, a_{Z}[g]$ )

(opisy na rysunach 8, 9, 11 i 12: Body longitudal acceleration - przyspieszenie wzdłużne $\left(\mathrm{a}_{X}\right)[\mathrm{g}]$,

Body lateral acceleration - przyspieszenie boczne $\left(\mathrm{a}_{Y}\right)[\mathrm{g}]$, Body normal acceleration przyspieszenie normalne $\left.\left(\mathrm{a}_{\mathrm{Z}}\right)[\mathrm{g}]\right)$

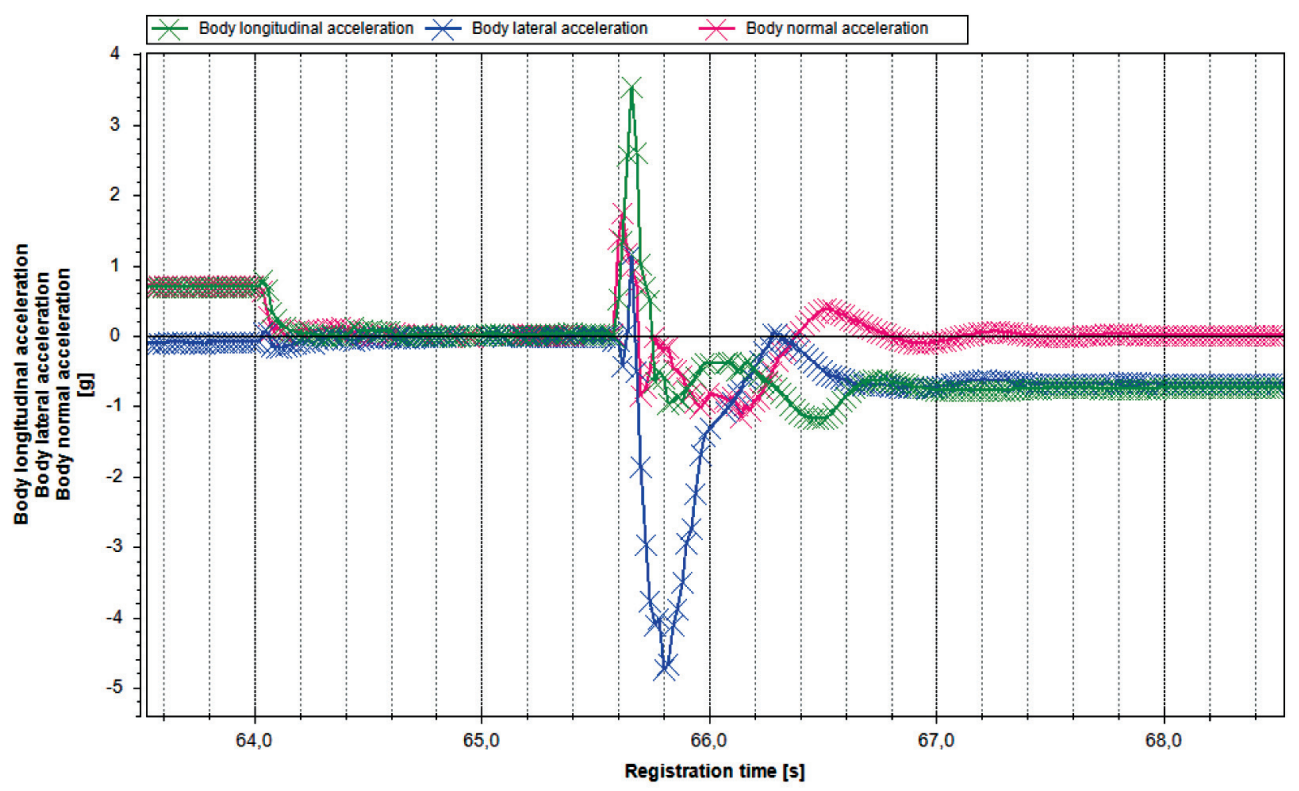

Rys. 9. Dane z rejestratora BAD - przyspieszenia podczas zrzutu nr 1 (przyspieszenia: $\mathrm{a}_{\mathrm{X}}, \mathrm{a}_{\mathrm{Y}}, \mathrm{a}_{\mathrm{Z}}[\mathrm{g}]$ ) 


\subsubsection{Badania pojedynczego układu poduszek (zrzut nr 2)}

\section{Głowa}

Sensor zamontowany wewnątrz głowy manekina zarejestrował przyspieszenia chwilowe, których wykres przedstawiono na rysunku 10. Największa wartość przyspieszenia wystąpiła na osi X i wynosiła $\mathrm{X}=23,29 \mathrm{~g}$ (190,84 s). Dodatnia wartość przyspieszenia na osi X oznacza ruch głowy „do przodu”, a ruch w tym kierunku nie stanowi aż tak dużego zagrożenia jak ruch głowy „do tyłu” (,ujemne” przyspieszenie osiągnęło wartość X = -2,91 g (190,94 s)), niemniej jednak przypuszcza się, że zarejestrowane przyspieszenie mogłoby wywołać u człowieka zagrożenie zdrowia, a nawet życia. Na pozostałych osiach zarejestrowane przyspieszenia chwilowe „dodatnie” wyniosły maksymalnie $\mathrm{Y}=+7,77 \mathrm{~g}(190,85 \mathrm{~s}), \mathrm{Z}=-11,91 \mathrm{~g}$ (190,86 s), a „ujemne” osiągnęły wartości sięgające na osi $\mathrm{Y}=-2,45 \mathrm{~g}(190,91 \mathrm{~s})$, a na osi $\mathrm{Z}=-4,63 \mathrm{~g}(190,83 \mathrm{~s})$. Ponadto na krzywiźnie określającej wartości przyspieszeń występującej na osi Z widać, że wystąpiły przyspieszenia „dodatnie”, „ujemne” oraz ponownie „dodatnie” (oznaczające ruch głowy „do góry”, „na dół” oraz ponownie „do góry”). Przyspieszenia na osiach wykraczające poza przedział $\{-2 \mathrm{~g}$ do $+3 \mathrm{~g}\}$ wystąpiły łącznie w czasie około $0,2 \mathrm{~s}$.

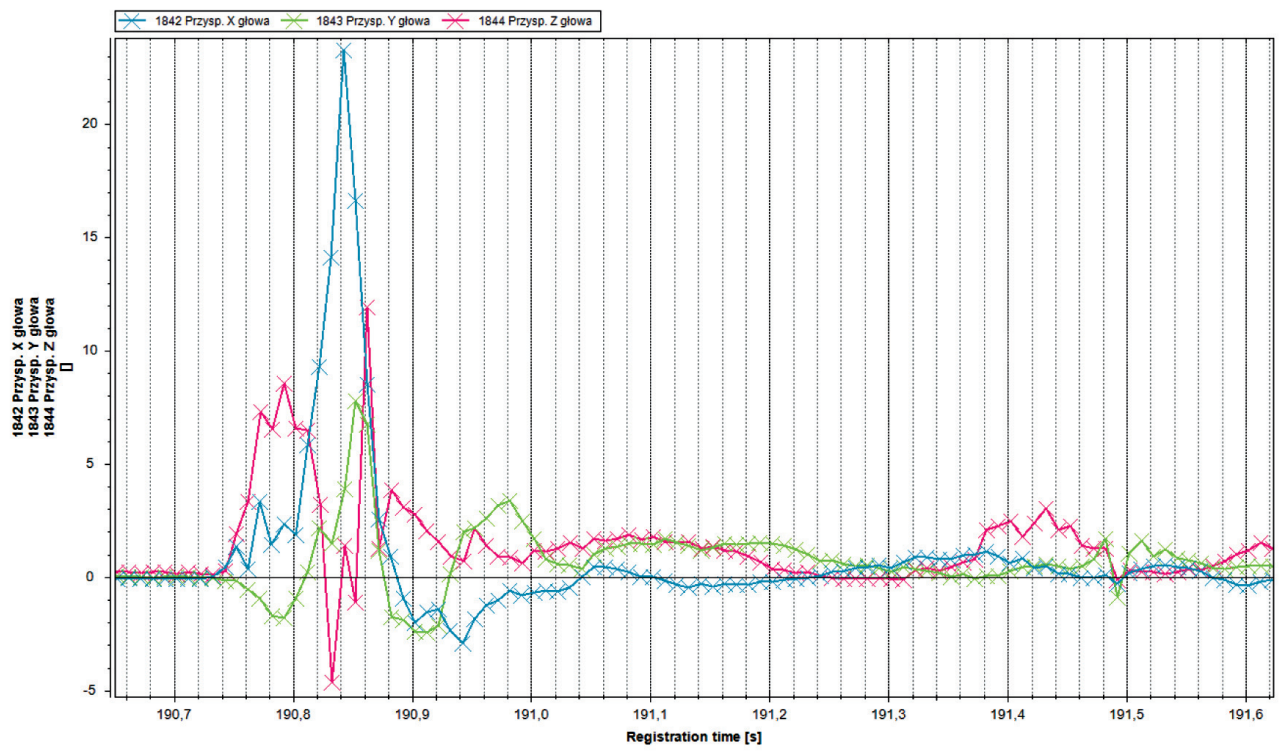

Rys. 10. Przyspieszenia [g] zarejestrowane przez sensor umieszczony wewnątrz głowy manekina

\section{Środek ciężkości}

Układ odniesienia AHRS zamontowano w miejscu, które przyjmuje się za środek ciężkości manekina. Zarejestrowane przez niego przyspieszenia chwilowe pokazuje 
rysunek 11. Przyspieszenia chwilowe występujące na osiach Y oraz Z zmieniały swoje wartości od „dodatnich” do „ujemnych” (oraz odwrotnie) w znacznie bardziej dynamiczny sposób niż przyspieszenia chwilowe w osi X. Maksymalna wartość przyspieszenia chwilowego na osi Y wyniosła $\mathrm{Y}=+6,76 \mathrm{~g}(190,88 \mathrm{~s})$. Łatwo można zauważyć na wykresie, że tylko w płaszczyźnie bocznej $\left(\mathrm{a}_{\mathrm{Y}}\right)$ wystąpiło przyspieszenie ujemne o wartościach poniżej -2 g i osiągnęło ono Y $=-5,69$ g (190,8 s). Skrajne wartości przyspieszeń na osi $Z$ osiągnęły $Z=+7,42$ g (190,77 s) oraz $Z=-1,75$ g (19,91 s), natomiast na osi X nie zarejestrowano przyspieszeń „ujemnych” w analizowanym fragmencie testu (obrazującym przyspieszenia chwilowe, które wystąpiły w wyniku upadku manekina). Największa wartość przyspieszenia zarejestrowanego na osi $\mathrm{X}$ wniosła $\mathrm{X}=+9,60 \mathrm{~g}(190,80 \mathrm{~s})$, a najmniejsza $\mathrm{X}=+0,216 \mathrm{~g}(191,50 \mathrm{~s})$.

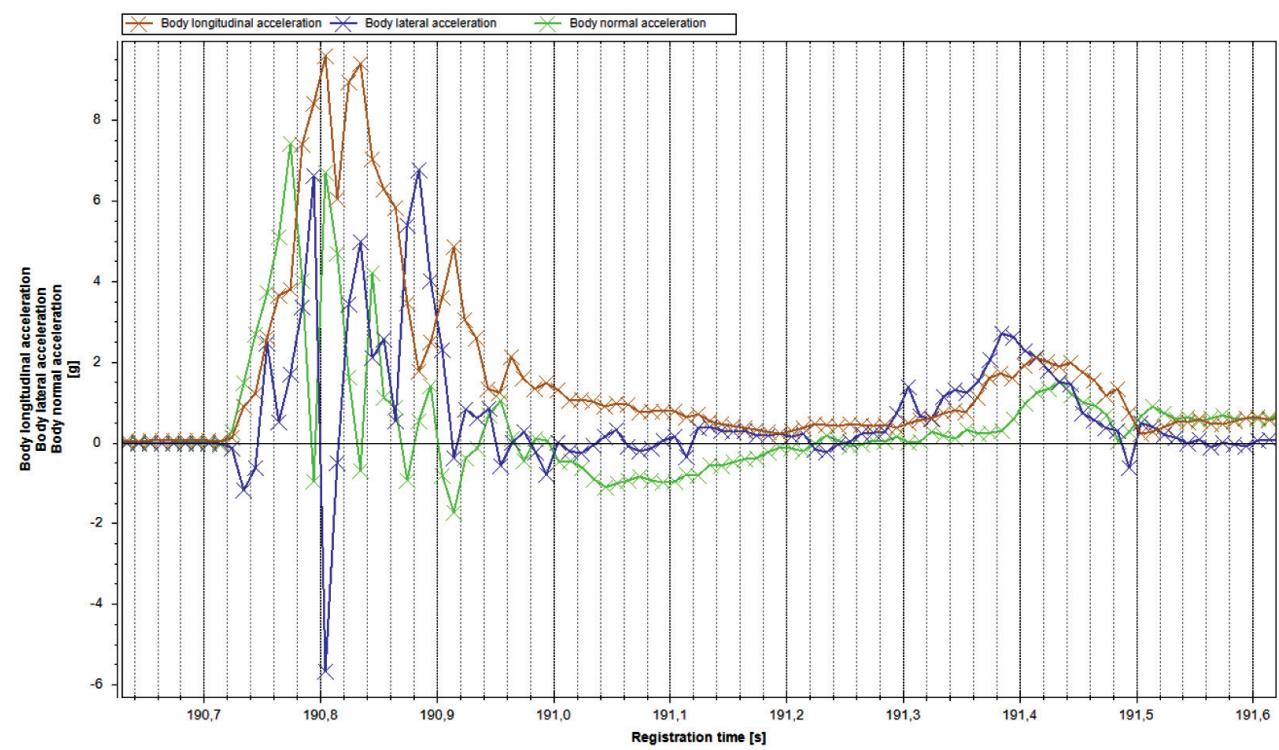

Rys. 11. Dane z AHRS - środek ciężkości (przyspieszenia: $a_{X}, a_{Y}, a_{Z}[g]$ )

Rejestrator BAD umieszczono na klatce piersiowej manekina także przy drugim zrzucie.

Maksymalne wartości zarejestrowanych przyspieszeń bezpośrednio po upadku na podwójne poduszki zabezpieczające podano poniżej (rys. 12):

- przyspieszenie wzdłużne $\mathrm{a}_{X}=+3,22 \mathrm{~g}$ (w 194,06 s),

- przyspieszenie boczne $\mathrm{a}_{\mathrm{Y}}=-2,84 \mathrm{~g}$ (w 194,16 s),

- przyspieszenie normalne $\mathrm{a}_{\mathrm{Z}}=+2,85 \mathrm{~g}$ (w 194,06 s). 


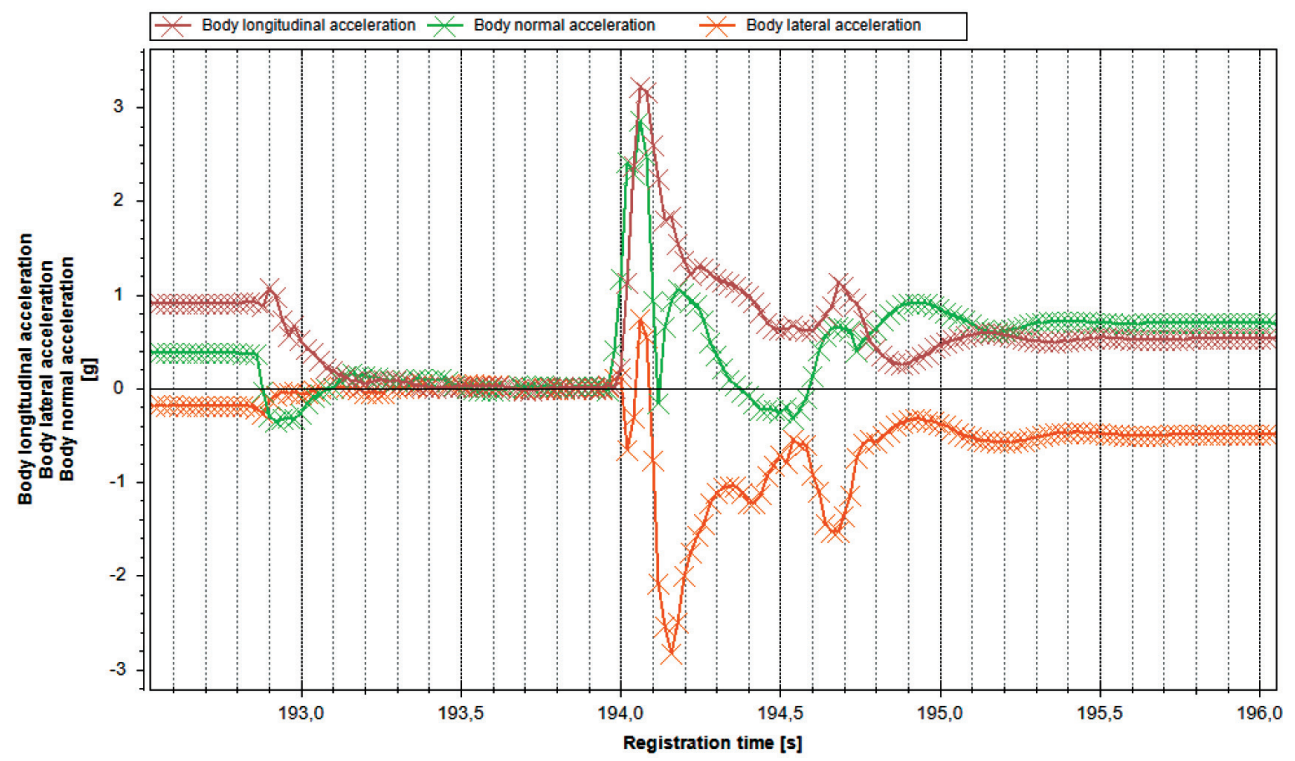

Rys. 12. Dane z rejestratora BAD - przyspieszenia podczas zrzutu nr 2 (przyspieszenia: $a_{X}, a_{Y}, a_{Z}[g]$ )

Po zarejestrowaniu przyspieszeń chwilowych rejestratorem BAD wyliczono przyspieszenia całkowite działające na korpus manekina. Przyspieszenie całkowite obliczono jako pierwiastek z sumy kwadratów przyspieszeń składowych ax, aa , a :

- podczas zrzutu nr 1 manekina na podwójną warstwę poduszek - maksymalne przyspieszenie całkowite wyniosło $4,77 \mathrm{~g}$ (rys. 13),

- podczas zrzutu nr 2 manekina na pojedynczą warstwę poduszek - maksymalne przyspieszenie całkowite wyniosło 4,32 g (rys. 14).

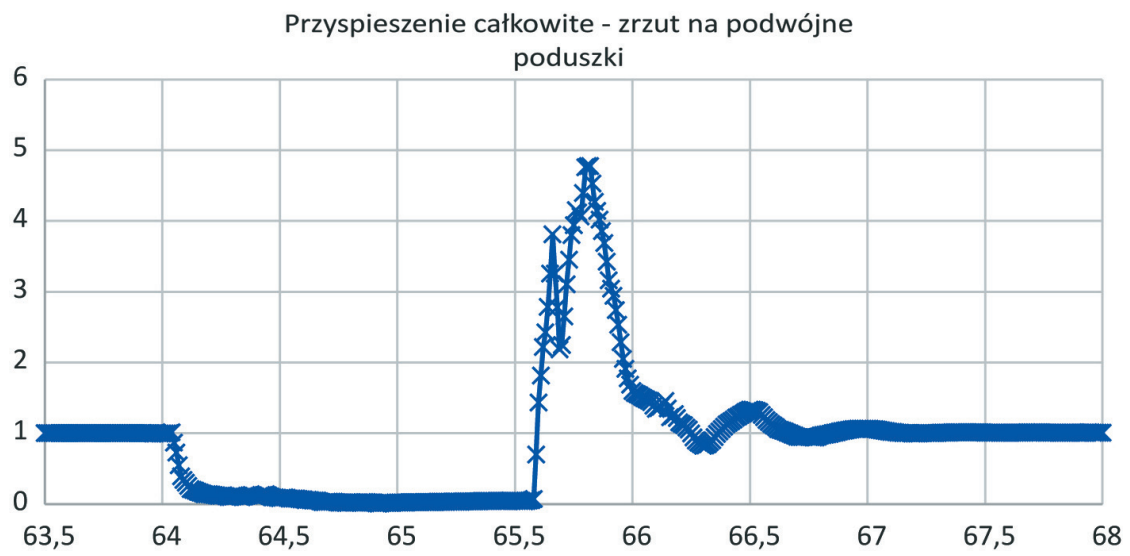

Rys. 13. Dane z rejestratora BAD - przyspieszenie całkowite podczas zrzutu nr 1 


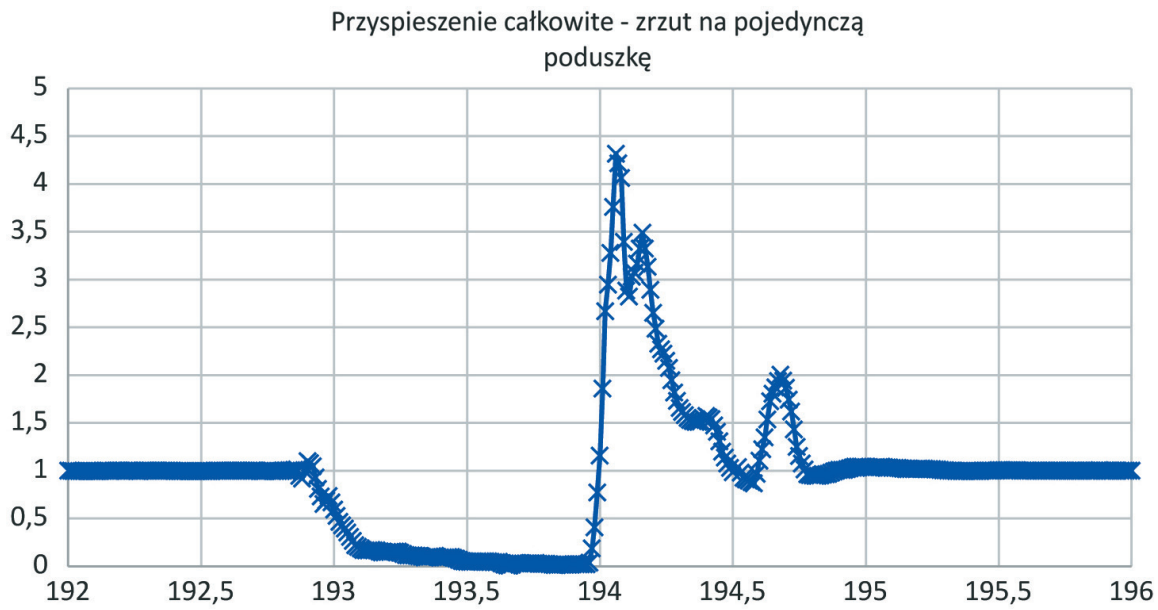

Rys. 14. Dane z rejestratora BAD - przyspieszenie całkowite podczas zrzutu nr 2

\section{Podsumowanie}

Z uwagi na położenie delikatnie ukrwionych organów (mózg, gałki oczne) kierunek przyspieszenia powoduje odpowiednio napływ lub odpływ krwi, co zmienia jej ciśnienie w tych narządach. W przypadku napływu krwi i wzrostu jej ciśnienia rośnie prawdopodobieństwo wystąpienia wylewów krwi do mózgu zagrażających zdrowiu i życiu lub do gałek ocznych, co grozi częściowym lub trwałym upośledzeniem widzenia. $\mathrm{Z}$ tego też powodu organizm człowieka dużo lepiej znosi przeciążenia dodatnie niż ujemne. Największe, jednak najkrócej działające, przeciążenia występują w trakcie katapultowania (w niektórych radzieckich konstrukcjach nawet 20-22 g, w zachodnich samolotach 12-14 g), podczas wyczynowej akrobacji lotniczej, podczas walki powietrznej samolotu myśliwskiego (do $10 \mathrm{~g}$ ) (Stoll 1956). Duże przeciążenia występują podczas szybkiego wyprowadzenia (wyrwania) samolotu z lotu nurkowego i ogólnie podczas wszystkich manewrów lotniczych wykonywanych podczas lotu z dużą prędkością po łuku.

W życiu codziennym stanu przeciążenia można doświadczyć np. w ruszającej lub zatrzymującej się windzie, w szybko zakręcającym (drifting) pojeździe lub pokonującym nierówności samochodzie (hopka), podczas silnego przyspieszania i hamowania autem, w czasie podróży samolotem - szczególnie gdy występują turbulencje.

Największe przeciążenia występują podczas wypadków drogowych, a także katastrof lotniczych - zwykle są one powodem obrażeń wielonarządowych. Przeciętny człowiek wytrzymuje przeciążenia do $5 \mathrm{~g}$.

W latach 60. amerykańskie wojsko i NASA przeprowadziły wiele eksperymentów próbujących określić ludzkie granice wytrzymałości. Wykonano ponad sto tysięcy 
10-sekundowych testów. Badania były wykonywane przy konstruowaniu kombinezonów antygrawitacyjnych. Poddawano ludzi przeciążeniom w czasie ok. 1,5 sekundy o wartości $25 \mathrm{~g}$ do prawie 2,5 minut dla przeciążenia $18 \mathrm{~g}$. Ludzie wytrzymali przeciążenia +3 g i +4 g przez godzinę.

W pierwszej próbie opisywanych testów manekin (spadający na dwie warstwy poduszek) uderzył w miejsce przylegania czterech poduszek. Następnie wsunął się pomiędzy poduszki. Czas wytracenia prędkości mierzony dwoma niezależnymi systemami (zabudowanym systemem w manekinie PRP-W2 oraz niezależnym systemem rejestracji BAD) nie przekraczał 0,5 s, a uśrednione zarejestrowane przyspieszenie całkowite wynosiło $5 \mathrm{~g}$.

W drugiej próbie manekin spadł na pojedynczą warstwę poduszek z zabezpieczeniem górnej powierzchni siatką. Również w tej próbie manekin wsunął się razem z siatką pomiędzy poduszki. W tym przypadku także zarejestrowane całkowite przyspieszenie miało wartość $5 \mathrm{~g}$.

W obu układach poduszek należy zarekomendować zamocowanie dodatkowej siatki na obrzeżach poduszek.

Przedstawione wyniki pomiarów uzyskane zostały przy upadku manekina z wysokości, jaką przyjmuje się podczas badania siatek bezpieczeństwa. Warto zaznaczyć, że wcześniej prowadzono również pomiary przy upadku manekina z mniejszej wysokości, ich wyniki nie zostały jednak przedstawione w niniejszym artykule. Zmiana orientacji ciała podczas spadania powoduje znaczną zmianę czynników narażeniowych powstałych w chwili upadku. Mając na uwadze przydatność prowadzonych badań, należy wykonać serię rejestrowanych upadków dla uzyskania pełnych danych statystycznych.

Wyniki badań dowodzą, że skokochrony mogą być z powodzeniem stosowane w ochronie przed upadkiem z wysokości, spełniając wymagania opisane w stosownych normach bezpieczeństwa i stanowiąc rozwiązanie alternatywne wobec siatek bezpieczeństwa.

\section{Literatura}

Bartsch A., Benzel E., Miele V., Morr D., Prakash V., 2012, Hybrid III anthropomorphic test device (ATD) response to head impacts and potential implications for athletic headgear testing, Accident Analysis \& Prevention, vol. 48, s. 285-291. https:// doi.org/10.1016/j.aap.2012.01.032.

DIN 14151-3, 2016, Rescue cushions - Part 3: Jumping cushion type 16 - Requirements, testing.

PN-EN 1263-1:2015-2, 2015, Tymczasowe konstrukcje stosowane na placu budowy Siatki bezpieczeństwa - Czesść 1: Wymagania bezpieczeństwa, metody badań. 
PN-EN 1263-2:2015-2, 2015, Tymczasowe konstrukcje stosowane na placu budowy Siatki bezpieczeństwa - Część 2: Wymagania bezpieczeństwa dotyczące instalowania siatek bezpieczeństwa.

PILC Józef Grzybowski, 2021, Raport z kalibracji. System monitorowania parametrów dynamicznych manekina Hybrid III z systemem rejestracji PRP-W2.

Stoll M., 1956, Human tolerance to positive $G$ as determined by the physiological end points, The Journal of Aviation Medicine, vol. 27(4), s. 356-367.

Tanaka Y., Yonezawa H., Hosokawa N., Matsui Y., Mizuno K., Yamaguchi M., Yoshida R., 2009, Responses of Hybrid III 3 YO and Q3 Dummies in Various CRSs Tested Using ECE R44 Impact Conditions, [w:] Proceedings of the 21st (ESV) International Technical Conference on the Enhanced Safety of Vehicles, June 2009, Stuttgart, Germany, National Highway Traffic Safety Administration, s. 23-29. 